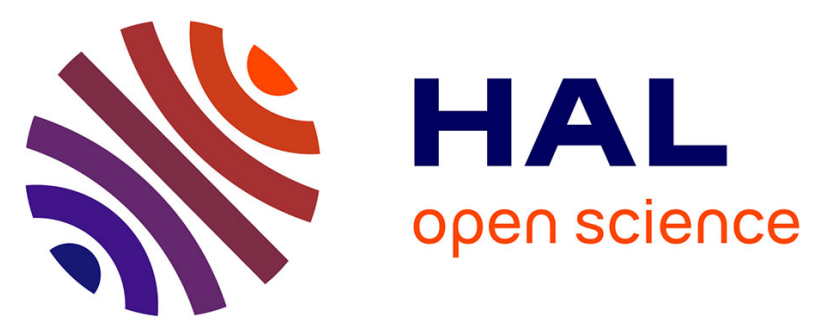

\title{
Pyruvate Aldolases Catalyze Cross-Aldol Reactions between Ketones: Highly Selective Access to Multi-Functionalized Tertiary Alcohols
}

Victor Laurent, Léa Gourbeyre, Alexandre Uzel, Virgil Hélaine, Lionel Nauton, Mounir Traïkia, Véronique de Berardinis, Marcel Salanoubat, Thierry Gefflaut, Marielle Lemaire, et al.

\section{To cite this version:}

Victor Laurent, Léa Gourbeyre, Alexandre Uzel, Virgil Hélaine, Lionel Nauton, et al.. Pyruvate Aldolases Catalyze Cross-Aldol Reactions between Ketones: Highly Selective Access to MultiFunctionalized Tertiary Alcohols. ACS Catalysis, 2020, 10 (4), pp.2538-2543. 10.1021/acscatal.9b05512 . hal-02907546

\section{HAL Id: hal-02907546 \\ https://hal.science/hal-02907546}

Submitted on 1 Dec 2020

HAL is a multi-disciplinary open access archive for the deposit and dissemination of scientific research documents, whether they are published or not. The documents may come from teaching and research institutions in France or abroad, or from public or private research centers.
L'archive ouverte pluridisciplinaire HAL, est destinée au dépôt et à la diffusion de documents scientifiques de niveau recherche, publiés ou non, émanant des établissements d'enseignement et de recherche français ou étrangers, des laboratoires publics ou privés. 


\title{
Pyruvate Aldolases Catalyze Cross-Aldol Reactions between Ketones: Highly Selective Access to Multi-Functionalized Tertiary Alcohols
}

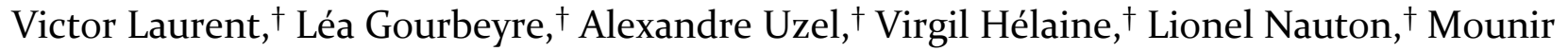 \\ Traïkia, ${ }^{\dagger}$ Véronique de Berardinis, ${ }^{\dagger}$ Marcel Salanoubat, ${ }^{\dagger}$ Thierry Gefflaut, ${ }^{\dagger}$ Marielle Lemaire ${ }^{\dagger}$ and \\ Christine Guérard-Hélaine*† \\ † Université Clermont Auvergne, CNRS, SIGMA Clermont, Institut de Chimie de Clermont-Ferrand, 63ooo Cler- \\ mont-Ferrand, France \\ \Génomique Métabolique, Génoscope, Institut François Jacob, CEA, CNRS, Univ Evry, Université Paris-Saclay, \\ 91057 Evry, France
}

\begin{abstract}
Tertiary alcohols are widely represented in nature and among bioactive molecules. Their importance is attested by the continuous efforts to meet the challenge of their stereoselective synthesis. In this context, we propose an enzymatic approach, involving class II pyruvate aldolases. These enzymes are shown to catalyze selective cross-aldol reactions between pyruvic acid or derivatives as nucleophiles and a series of ketones as electrophiles. This catalytic activity is exemplified by the highly stereoselective preparation of seven branched ketols with good yields. One of them was readily converted into a constrained 4-hydroxyproline analogue in a multi-enzymatic one-pot one-step process.
\end{abstract}

KEYWORDS: pyruvate aldolase, tertiary alcohol, proline analogue, cascade reaction, transaminase

Tertiary alcohols are important motifs in pharmaceuticals, as well as being fine and specialty chemicals, such as chiral ligands, ${ }^{1-3}$ building blocks in asymmetric synthesis, ${ }^{4-}$ ${ }^{6}$ and solvents. ${ }^{6-9}$ Many bioactive compounds with these moieties are known, such as tramadol (analgesic), erythromycin (antibiotic), doxorubicin (antitumor agent), and ethynylestradiol (estrogen), along with many ethers, esters, and acetals derived from tertiary alcohols. However, the challenges to surmount for their synthesis are as high as the demand for enantiopure tertiary alcohols.7,9 Recently, DHAP-dependent class II aldolases were shown to be active with ketones as electrophile substrates, thus allowing the stereoselective synthesis of a series of tertiary alcohols. $^{10}$ Therefore, we examined whether other members of the aldolase family display the same catalytic power. We assumed that this exceptional activity could be shared with other class II aldolases, as the enolate intermediate $^{11}$ formed in the active site of class-II aldolases should be more nucleophilic than the enamine intermediate characteristic of class I aldolases. Among the aldolase family, pyruvate aldolases may be good candidates for this purpose, as some of them belong to the class II aldolases. In addition, they have been well studied ${ }^{11,12}$ because of their role in metabolism and their ability to provide chiral synthons with high potential in total synthesis. Until the discovery of DHAP-dependent aldolases in $2018,{ }^{10} 4$-hydroxy-4-methyl-2-oxoglutarate/4-carboxy-4-hydroxy-2- oxoadipate aldolases ${ }^{13,14}$ were the sole aldolases able to catalyze the formation of tertiary alcohols. They naturally catalyze the self-addition of pyruvate or the addition of pyruvate onto oxaloacetate. Nevertheless, this type of reaction is limited by the substrate scope of the enzymes.13,14 The sole example of cross-coupling of $\alpha$-keto acids at a preparative scale is the development of the enzymatic synthesis of monatin, a natural sweetener. ${ }^{11,15,16}$ Recently, a collection of 21 class-II pyruvate aldolases from biodiversity, including RhmA, GarL and $\mathrm{HpcH}$ from E. coli, were shown to display high synthetic potential due to their exceptional tolerance towards nucleophile substrates, such as hydroxypyruvate or ketobutyrate. ${ }^{17,18}$ This property remains rare as aldolases are generally named according to their strict specificity for their nucleophilic substrate. Here, we further explored the catalytic potential of this enzyme set by testing aldol reactions with various ketones as electrophiles in combination with pyruvic acid or derivatives.

First, the enzyme collection was assayed under standard conditions $(1 \mathrm{mg} / \mathrm{mL})$ with pyruvic acid $1(20 \mathrm{mM})$ as the unique substrate to assess the self-addition reaction. Aldol formation was not observed with any pyruvate aldolase. Subsequently, three simple ketones (8o mM) were evaluated as potent electrophiles with 1 (20 mM) (Figure 1). These ketones could be classified into two groups: not activated (acetone: 4), activated by either one hydroxyl (hydroxyacetone: 5) or two hydroxyls (dihydroxyacetone: 6). All tested enzymes displayed the same activity profile: an 
aldol adduct was exclusively formed with ketone $\mathbf{6}$, with complete conversion of $\mathbf{1}$ within 2 to $5 \mathrm{~h}$ (see SI). The two other less electrophilic ketones 4 and 5 did not undergo any significant reaction under our analytical conditions. Next, in order to select the most promising enzymes with the largest application scopes, ketones 4 to $\mathbf{6}$ were assayed with 2-oxobutyric acid $\mathbf{2}$ or hydroxypyruvic acid 3 as nucleophile substrates (20 $\mathrm{mM})$, as these enzymes are known to accept them as nucleophiles with an aldehyde as electrophile. ${ }^{17,18}$ Again, as described for $\mathbf{1}$, the self-addition reactions of keto acids $\mathbf{2}$ and $\mathbf{3}$ was first assessed. Although no reaction was observed with $\mathbf{2}$ as a unique substrate (see SI), partial or complete conversion of $\mathbf{3}$ was observed with several enzymes. Given that the hydroxyl group of $\mathbf{3}$ provides an activating effect, the self-addition of $\mathbf{3}$ is consistent with the results obtained with ketones 4 to $\mathbf{6}$. Consequently, 3 was not further used as a nucleophile in this study. Substrate $\mathbf{2}$ was then combined with ketones 4 to 6 in the presence of the various aldolases. As already observed with $\mathbf{1}$ as nucleophile, an aldolisation product was obtained only with ketone $\mathbf{6}$. However, different reactivity profiles were observed. Indeed, only six enzymes were able to completely convert $\mathbf{2}$ into the corresponding tertiary alcohol in a few hours (see SI): Uniprot Id. QoK203, B4XH86, $\mathrm{A}_{5} \mathrm{VAX}_{1}, \mathrm{~A}_{9} \mathrm{EoU}_{5}, \mathrm{~A}_{3} \mathrm{SLSo}$, and $\mathrm{I}_{7} \mathrm{DKY}$ (deleted entry in UniProtKB, currently given by the UniParc ID UPIooo16oF944). QoK203 was shown in a previous study to display very low stereoselectivity with $\mathbf{2}^{18}$ and was discarded for the following experiments. Hence, five pyruvate aldolases were assayed in aldolisation reactions using $\mathbf{1}$ and $\mathbf{2}$ as nucleophiles combined with three other activated ketones as potent electrophile substrates: L-erythrulose 7 , Dfructose $\mathbf{8}$, and 1,3-difluoroacetone $\mathbf{9}$ (Figure 1).

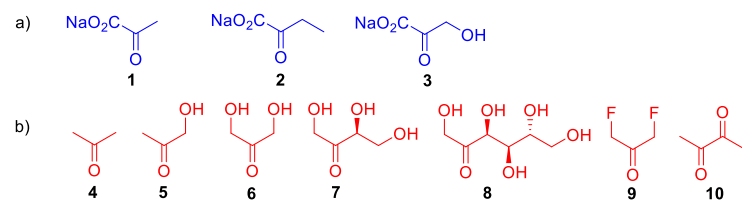

Figure 1. Nucleophiles a) and electrophiles b) evaluated with class II pyruvate aldolases from biodiversity.

There was no aldol addition observed between $\mathbf{1}$ and $\mathbf{8}$, regardless of the enzyme tested. Such lack of reactivity with $\mathbf{8}$ may result from the accommodation limit of the substrate binding sites or the favored cyclisation of $\mathbf{8}$, protecting the ketone from nucleophilic addition. Ketone 2 was therefore not tested with this electrophile. Conversely, the acyclic ketone $\mathbf{7}$ proved to behave as a substrate of the tested aldolases, although activity was less than that observed for the shorter ketone 6. Aldolases B4XH86 and $\mathrm{A}_{5} \mathrm{VAX}_{1}$ were the most efficient catalysts for the aldolisation between 1 and 7 , with almost $80 \%$ conversion in $2 \mathrm{~h}$ (Figure 2). There was an additional decrease in aldolase activity when nucleophile $\mathbf{2}$ was used in combination with $\mathbf{7}$. Nevertheless, approximately $80 \%$ conversion could be achieved in $30 \mathrm{~h}$ by $\mathrm{A}_{5} \mathrm{VAX}_{1}$ and $\mathrm{B}_{4} \mathrm{XH} 86$ with this substrate couple. For the aldol reaction of $\mathbf{1}$ with $\mathbf{9}$, complete conversion of 1 occurred in three hours with four of the selected enzymes (all except I7DKYo, Figure 2). The enzyme activity was lower when $\mathbf{2}$ was used as a nucleophile in combination with $\mathbf{9}$, for which the conversion rate never exceeded $50 \%$ after $48 \mathrm{~h}$ (data not shown).

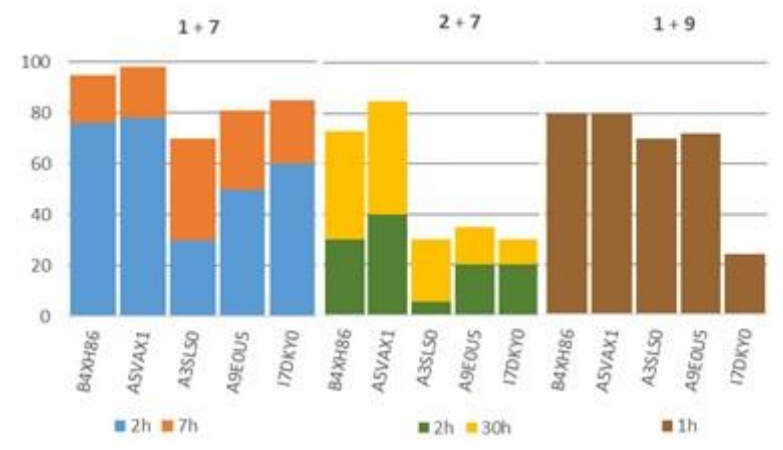

Figure 2. Conversion of nucleophiles 1 or $2(20 \mathrm{mM})$ in the presence of ketones 7 or $\mathbf{9}(80 \mathrm{mM})$ with the selected aldolases

To note, the best performing above-mentioned enzymes were able to convert the considered electrophile ketones with an acceptable rate relative to that of structurally close aldehydes. Indeed, for example, DHA was converted only two times slower than D-glyceraldehyde using B4XH86 and 2 as nucleophile.

The promising analytical data obtained with ketones $\mathbf{6}$, 7 , and 9, prompted us to carry out preparative syntheses at the 50-mg scale using a concentration of $20 \mathrm{mM}$ for the nucleophiles and $80 \mathrm{mM}$ for the electrophiles, to isolate aldol adducts for their full characterization and stereoselectivity assignments.

No asymmetric carbon was formed for the aldol reaction $\mathbf{1}+\mathbf{6}$ (Scheme 1), so all five enzymes were expected to give the same aldol. B4XH86, one of the most promising aldolases, was thus chosen for this synthesis. The achiral aldol 11 was isolated with a $92 \%$ yield after $8 \mathrm{~h}$ reaction and anion exchange chromatography for purification. NMR analysis showed that $\mathbf{1 1}$ exists in solution as an equimolar mixture of furanose derivatives.

Aldolisation of $\mathbf{2}$ and $\mathbf{6}$ led to the formation of one asymmetric center on carbon 3 of aldol 12 (Scheme 1). The five selected enzymes were $3 \mathrm{~S}$ specific when using 2 as nucleophile (see previous study ${ }^{18}$ or below for aldol reaction $2+7$ concerning $\mathrm{A}_{3} \mathrm{SLSo}$ ). Thus, the five enzymes again yielded the same aldol. B4XH86 was again chosen as catalyst and product 12 was obtained after $12 \mathrm{~h}$ with a yield of $75 \%$. Aldol 12 was observed in solution as two major furanose forms with roughly the same ratio.

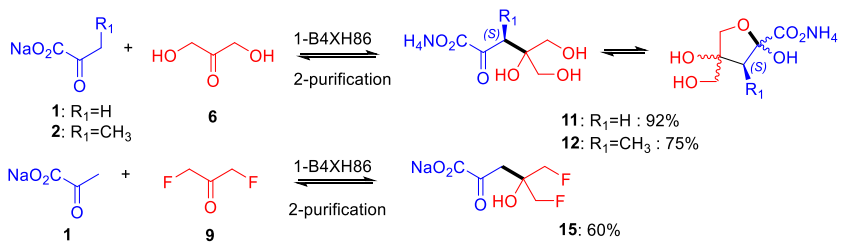

Scheme 1. Aldolase-catalyzed reactions of pyruvate 1 or 2-ketobutyrate 2 with dihydroxyacetone 6 and difluoroacetone 9 .

Aldol reaction $\mathbf{1}+\mathbf{7}$ (Scheme 2) resulted in the formation of only one chiral center at $\mathrm{C}_{4}$ of aldol 13. In theory, a non- 
stereoselective enzyme could lead to the production of a total of twelve cyclic aldols, i.e. two epimers in the fourth position with three possible cyclic forms and potential alpha/beta anomerism (Scheme 2). Therefore, DEPT ${ }^{13} \mathrm{C}$ NMR experiments were first performed to focus on the tertiary carbon of the various forms (see SI). These analyses revealed that the most active enzymes, $\mathrm{B}_{4} \mathrm{XH} 86$ and $\mathrm{A}_{5} \mathrm{VAX}_{1}$, displayed poor stereoselectivity, with a mixture of nine forms observed by NMR. Conversely, with the most stereoselective aldolase $\mathrm{A}_{3} \mathrm{SLS}$, only six forms were observed, suggesting a possible unique configuration at $\mathrm{C}_{4}$. This assumption was confirmed by NMR studies performed on the decarboxylated aldol product. This decarboxylation reaction was run with $\mathrm{H}_{2} \mathrm{O}_{2}$ in a buffered solution $(\mathrm{pH} 7.5$ to avoid the lactonization observed without buffer) and led to the formation of only one linear stereoisomer (> $95 \%$ by ${ }^{1} \mathrm{H}$ NMR). Subsequently, $2 \mathrm{D}$ NOESY NMR experiments revealed the $(4 S)$ configuration of $\mathbf{1 3}$, as shown by correlations between $\mathrm{H}_{3}, \mathrm{H}_{7}$, and $\mathrm{H}_{5}$ of the major pyranose form (see SI). Finally, although A3SLSo was analytically found to be the least effective aldolase for catalyzing the coupling $1+7$, the reaction was fast enough $(15 \mathrm{~h})$ to selectively provide the aldol $\left(4 S,{ }_{5} S\right)-13$ at an $85 \%$ yield after purification by anion exchange chromatography.

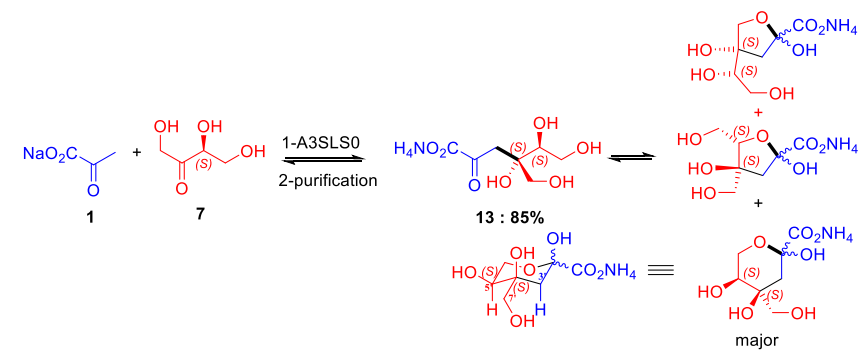

Scheme 2. Aldolase-catalyzed reaction of pyruvate with L-erythrulose: $1+7$.

Aldol reaction $2+7$, was also thoroughly examined (Scheme 3). As observed at the analytical scale, reactions with 2 as nucleophile were much slower than those run with 1. Consequently, aldolases $\mathrm{A}_{5} \mathrm{VAX}_{1}$ and $\mathrm{B}_{4} \mathrm{XH} 86$, which gave the best conversions in a reasonable time (24 h), were selected for preparative-scale syntheses. After purification on an anionic exchange resin, aldol 14 was isolated in $90 \%$ and $74 \%$ yields, respectively. From the twelve theoretical cyclic forms that could be obtained (strict $3 S$ configuration), in contrast from $\mathbf{1}$, only three appeared on the NMR spectra for both enzymes, 2 furanoses $\mathbf{1 4} \mathbf{b}$ and one pyranose 14c (Scheme 3), all in the same proportion. Additional 2D NOESY NMR experiments allowed to assign the configurations $\left({ }_{3} S,{ }_{4} S,{ }_{5} S\right)$ to the aldol formed for both enzymes. As expected, the configuration at $\mathrm{C}_{4}$ was the same for both aldols 13 and $\mathbf{1 4}$, resulting from the similar addition mode on the re face of 7 . The reaction was also performed under the same conditions with $\mathrm{A}_{3} \mathrm{SLSo}$ to assess its stereoselectivity at carbon 3, as no previous studies had been conducted with this enzyme. An identical NMR spectrum was obtained as that for $\mathrm{A}_{5} \mathrm{VAX}_{1}$, also showing a ${ }_{3} S$ preference with $\mathbf{2}$. However, the reaction did not exceed $50 \%$ conversion after $48 \mathrm{~h}$.

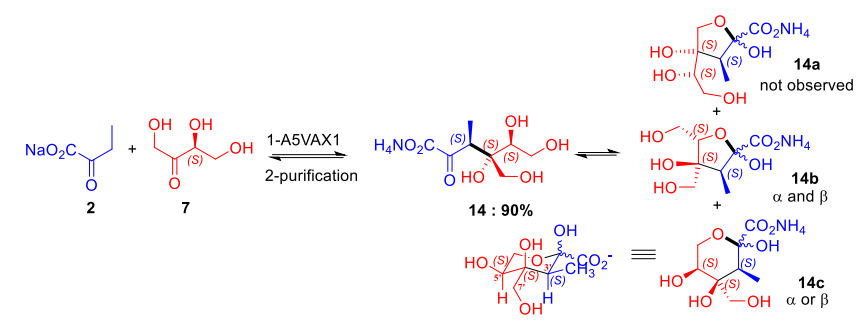

Scheme 3. Aldolase-catalyzed reaction of 2-ketobutyrate with L-erythrulose: $2+7$.

The reaction of $\mathbf{1}$ with symmetrical difluoroketone $\mathbf{9}$ also led to an achiral aldol product $\mathbf{1 5}$ (Scheme 1). The aldol reaction $\mathbf{1}+\mathbf{9}$ was thus also performed with $\mathrm{B} 4 \mathrm{XH} 86$, previously identified in analytical experiments as one of the most active aldolases with this substrate couple. However, the reaction and purification process were hampered by the volatility of $\mathbf{9}$ and the limited stability (degradation on ion exchange resin) of $\mathbf{1 5}$ (see SI). Nevertheless, aldol 15 could be isolated at a yield of $60 \%$ after $7 \mathrm{~h}$.

We applied the methodology for the highly efficient preparation of a new constraint dehydro-proline analogue, to demonstrate the usefulness of this new route to tertiary alcohols. L-proline is an amino acid of particular interest due to its involvement in peptide and protein folding. Many proline analogues have been included in peptides and mimetics behaving as ligands for various therapeutic targets in the field of cancer, neuropathic pain, and autoimmune diseases. ${ }^{19}$ Furthermore, naturally occurring 4-hydroxy-L-proline is found in plant and animal proteins, such as collagen and gelatin, ${ }^{20}$ or in peptide antibiotics produced by several microorganisms. ${ }^{21}$ It has also been shown to display antioxidant properties in halotolerant and halophilic microorganisms, ${ }^{22}$ and has been used in polyamides as a porogen filler for bone reconstruction. ${ }^{23}$

The new targeted constrained hydroxyproline analogue 17 was readily prepared in a one-pot one-step process, including an enzymatic transamination of aldol $\mathbf{1 6}$ coming from the aldolisation reaction $\mathbf{1}+\mathbf{1 0}$ (Scheme 4). The aldolisation step was preliminary studied with the five previously selected aldolases. B4XH86 and A5VAX1 gave the best results at an analytical scale (total conversion of $\mathbf{1}$ in less than half an hour), $\mathrm{A}_{3}$ SLSo being the sole inactive enzyme under our experimental conditions. The aldol reaction was first performed using $\mathrm{A}_{5} \mathrm{VAX}_{1}$ as catalyst. As observed for 15, purification by anion exchange chromatography led to partial degradation of $\mathbf{1 6}$. Consequently, the excess diketone 10 was simply removed by liquid extraction and aldol 16 was thus obtained at a yield of $51 \%$ in a linear form 16a and a cyclic hydrate $\mathbf{1 6 b}$ in the same proportion. Subsequently, aldol $\mathbf{1 6}$ was used as a substrate for branched chain aminotransferase (BCAT) from Escherichia coli in the presence of glutamic acid (Glu) as amino donor. BCAT is a well-known enzyme that has already been used in many studies to prepare various amino acids of the Lseries with very high stereoselectivity. ${ }^{24-26}$ Thus, as expected, aldol 16 was converted into the corresponding $\alpha$ amino acid, which spontaneously underwent cyclization to give a mixture of $\mathbf{1 7} \mathbf{a}$ and $\mathbf{1 7} \mathbf{b}$ (Scheme 4). Cyclic imines were the only forms observed by NMR, suggesting that the 
cyclization could afford an efficient equilibrium shift of the transamination, as reported in similar cases using diamino or dicarbonyle derivatives as transamination substrates. ${ }^{27}$ ${ }^{29}$ In our case, it appeared that conversion of $\mathbf{1 6}$ did not exceed $60 \%$ (see SI). Nevertheless, assuming that BCAT exclusively produces amino acids of the L-series, the formation of $17 \mathbf{a}$ and $\mathbf{1 7} \mathbf{b}$ in equimolar quantities indicates that aldolisation was not stereoselective and led to racemic $16 a$.

Given that such a lack of enantioselectivity could be the result of a thermodynamic control of the aldol reaction, $\mathrm{A}_{5} \mathrm{VAX} 1$ and $\mathrm{BCAT}$ were combined in a one pot one step process to favor kinetic control and a possible improvement in stereoselectivity. Transamination was thus made irreversible through its coupling with the reduction of the coproduct 2-oxoglutaric acid (OG) formed from Glu. This reaction was catalyzed by an OG-reductase ${ }^{30,31}$ in the presence of NADH, which was itself irreversibly regenerated using the formate/formate dehydrogenase (FDH) system..$^{32}$ These cascade reactions were achieved by adjusting the relative amounts of $\mathrm{A}_{5} \mathrm{VAX}_{1}$ and BCAT to slow down the aldolisation reaction, while trying to minimize the side transamination reaction between $\mathbf{1}$ and Glu, leading to the formation of alanine. Finally, the pyrroline $\mathbf{1 7} \mathbf{a}$ and $\mathbf{1 7} \mathbf{b}$ were isolated after $8 \mathrm{~h}$ at a yield of $57 \%$ at a $25 / 75$ ratio using an $\mathrm{A}_{5} \mathrm{VAX} / \mathrm{BCAT}$ ratio of $1 / 40 \mathrm{w} / \mathrm{w}$ in this multi-enzyme one pot process, with 20,80 and $20 \mathrm{mM} \mathrm{1,} \mathrm{10,} \mathrm{and}$ Glu, respectively. The use of $\mathrm{B} 4 \mathrm{XH} 86$ in the same one step process gave a $35 / 65$ ratio of $\mathbf{1 7} \mathbf{a}$ and $\mathbf{1 7} \mathbf{b}$ (purification was not performed). The cis $(S, S)$ configuration of the major isomer $\mathbf{1 7} \mathbf{b}$ could be unambiguously assigned by NOESY ${ }^{1} \mathrm{H}$ NMR experiments (Scheme 4).

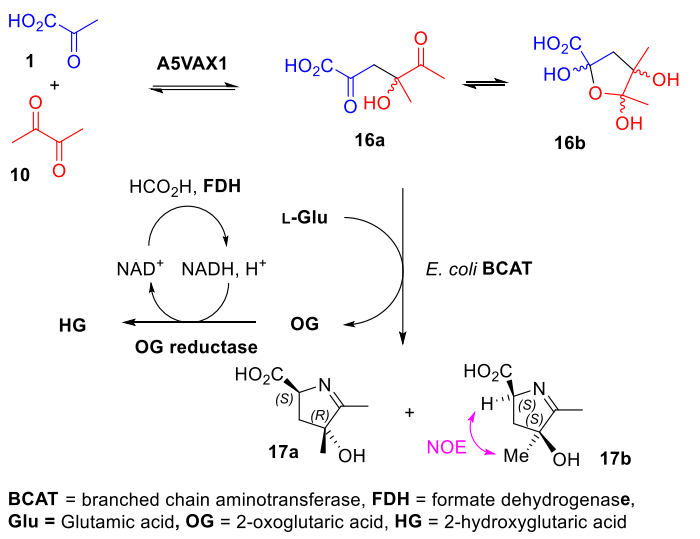

Scheme 4. Multienzymatic cascade synthesis of 4-hydroxy proline analogues $17 \mathrm{a}$ and $17 \mathrm{~b}$.

In conclusion, we highlight a second class II family of aldolases, namely pyruvate-aldolases, which are able to use ketones as electrophiles. However, the ketone substrate spectrum of these biocatalysts is more restricted than that of the Rhamulose-1-phosphate aldolases previously described, ${ }^{10}$ with selective activity towards the more highly activated ketones. Nevertheless, compared to DHAP aldolases, which are highly specific for their nucleophile substrate, pyruvate aldolases display significant activity with pyruvate analogues, thus opening access to structural diversity. This wide scope of application was illustrated in this study by the stereoselective preparation of seven new compounds isolated in moderate to very good yields $(60-$ 92\%). Finally, a one-pot one-step cascade process, involving four enzymes, was designed for the highly efficient and stereoselective synthesis of a new constrained dehydroproline analogue.

\section{AUTHOR INFORMATION}

Corresponding Author

*E-mail: christine.helaine@uca.fr.

ORCID

Christine Guérard-Hélaine : oooo-ooo2-2311-7514

Notes

The authors declare no competing financial interest.

\section{ASSOCIATED CONTENT}

Supporting Information.

The supporting information is available free of charge on the ACS Publications Website at DOI:

Details on material, methods, experimental procedures and spectral data.

\section{ACKNOWLEDGMENTS}

This work was supported by the French National Center for Scientific Research (CNRS) and the University of Clermont Auvergne.

\section{REFERENCES}

(1) Huang, X.-R.; Chen, C.; Lee, G.-H.; Peng, S.-M. A Spirocyclic Chiral Borate for Catalytic Enantioselective Nozaki-Hiyama Allylation of Ketones. Adv. Synth. Catal. 2009, 351, 3089-3095.

(2) Infante, R.; Gago, A.; Nieto, J.; Andrés, C. Enantiocontrolled Synthesis of Tertiary $\alpha$-Hydroxy- $\alpha$-Ynyl Esters by Dimethylzinc-Mediated Addition of Alkynes to $\alpha$-Keto Esters. Adv. Synth. Catal. 2012, 354, 2797-2804.

(3) Infante, R.; Nieto, J.; Andrés, C. Highly Homogeneous Stereocontrolled Construction of Quaternary Hydroxyesters by Addition of Dimethylzinc to $\alpha$-Ketoesters Promoted by Chiral Perhydrobenzoxazines and B(OEt)3. Chem. - Eur. J. 2012, 18, 43754379.

(4) Naredla, R. R.; Klumpp, D. A. Contemporary Carbocation Chemistry: Applications in Organic Synthesis. Chem. Rev. 2013, 113, 6905-6948.

(5) Chen, L.; Yin, X.-P.; Wang, C.-H.; Zhou, J. Catalytic Functionalization of Tertiary Alcohols to Fully Substituted Carbon Centres. Org. Biomol. Chem. 2014, 12, 6033-6048.

(6) Liu, Y.-L.; Lin, X.-T. Recent Advances in Catalytic Asymmetric Synthesis of Tertiary Alcohols via Nucleophilic Addition to Ketones. Adv. Synth. Catal. 2019, 361, 876-918.

(7) Müller, M. Enzymatic Synthesis of Tertiary Alcohols. ChemBioEng Rev. 2014, 1, 14-26.

(8) Kourist, R.; Bornscheuer, U. T. Biocatalytic Synthesis of Optically Active Tertiary Alcohols. Appl. Microbiol. Biotechnol. 2011, 91, 505-517.

(9) Gaggero, N. Building Up Quaternary Stereocenters Through Biocatalyzed Direct Insertion of Carbon Nucleophiles on Ketones: Building Up Quaternary Stereocenters Through Biocatalyzed Direct Insertion of Carbon Nucleophiles on Ketones. Eur J. Org. Chem. 2019, 2019, 7615-7628. 
(10) Laurent, V.; Darii, E.; Aujon, A.; Debacker, M.; Petit, J.L.; Hélaine, V.; Liptaj, T.; Breza, M.; Mariage, A.; Nauton, L.; Traïkia, M.; Salanoubat, M.; Lemaire, M.; Guérard-Hélaine, C.; de Berardinis V. Synthesis of Branched-Chain Sugars with a DHAPDependent Aldolase: Ketones Are Electrophile Substrates of Rhamnulose-1-Phosphate Aldolases. Angew. Chem. Int. Ed. 2018, 57, 5467-5471.

(11) Clapés, P.; Garrabou, X. Current Trends in Asymmetric Synthesis with Aldolases. Adv. Synth. Catal. 2011, 353, 2263-2283.

(12) Fesko, K.; Gruber-Khadjawi, M. Biocatalytic Methods for C-C Bond Formation. ChemCatChem 2013, 5, 1248-1272.

(13) Maruyama, K. Purification and Properties of 4-Hydroxy4-Methyl-2-Oxoglutarate Aldolase from Pseudomonas Ochraceae Grown on Phthalate. J. Biochem. (Tokyo) 1990, 108, 327-333.

(14) Maruyama, K.; Miwa, M.; Tsujii, N.; Nagai, T.; Tomita, N.; Harada, T.; Sobajima, H.; Sugisaki, H. Cloning, Sequencing, and Expression of the Gene Encoding 4-Hydroxy-4-Methyl-2-Oxoglutarate Aldolase from Pseudomonas Ochraceae NGJ1. Biosci. Biotechnol. Biochem. 2001, 65, 2701-2709.

(15) Sugiyama, M.; Watanabe, K.; Funakoshi, N.; Amino, Y.; Kawahara, S.; Takemoto, T. Process for Production of Glutamic Acid Derivatives. WO/2003/056026, July 10, 2003.

(16) Sugiyama, M.; Watanabe, K. Novel Aldolases and Process for Producing Substituted Alpha-Keto Acid. WO/2004/o18672, March 4, 2004.

(17) Berardinis, V. de; Guérard-Hélaine, C.; Darii, E.; Bastard, K.; Hélaine, V.; Mariage, A.; Petit, J.-L.; Poupard, N.; Sánchez-Moreno, I.; Stam, M.; Gefflaut, T.; Salanoubat, M.; Lemaire, M. Expanding the Reaction Space of Aldolases Using Hydroxypyruvate as a Nucleophilic Substrate. Green Chem. 2017, 19, $519-526$.

(18) Laurent, V.; Uzel, A.; Hélaine, V.; Nauton, L.; Traïkia, M.; Gefflaut, T.; Salanoubat, M.; de Berardinis, V.; Lemaire, M.; Guérard-Hélaine, C. Exploration of Aldol Reactions Catalyzed by Stereoselective Pyruvate Aldolases with 2-Oxobutyric Acid as Nucleophile. Adv. Synth. Catal. 2019, 361, 2713-2717.

(19) Kim, M.; Jeon, J.; Song, J.; Suh, K. H.; Kim, Y. H.; Min, K. H.; Lee, K.-O. Synthesis of Proline Analogues as Potent and Selective Cathepsin S Inhibitors. Bioorg. Med. Chem. Lett. 2013, 23, 3140-3144.

(20) Creighton, T. E. Proteins: Structures and Molecular Properties, $2^{\text {nd }}$ ed.; W. H. Freeman: New-York, 1993; p 96.

(21) Katz, E.; Kamal, F.; Mason, K. Biosynthesis of Trans-4Hydroxy-L-Proline by Streptomyces Griseoviridus. J. Biol. Chem. 1979, 254, 6684-669o.

(22) Kim, K. H.; Jia, B.; Jeon, C. O. Identification of Trans-4Hydroxy-L-Proline as a Compatible Solute and Its Biosynthesis and Molecular Characterization in Halobacillus Halophilus. Front. Microbiol. 2017, 8. 2054.

(23) Puska, M.; Yli-Urpo, A.; Vallittu, P.; Airola, K. Synthesis and Characterization of Polyamide of Trans-4-Hydroxy-L-Proline Used as Porogen Filler in Acrylic Bone Cement. J. Biomater. Appl. 2005, 19, 287-301.

(24) Xian, M.; Alaux, S.; Sagot, E.; Gefflaut, T. Chemoenzymatic Synthesis of Glutamic Acid Analogues: Substrate Specificity and Synthetic Applications of Branched Chain Aminotransferase from Escherichia Coli. J. Org. Chem. 2007, 72, 7560-7566.

(25) Ogawa, J.; Yamanaka, H.; Mano, J.; Doi, Y.; Horinouchi, N.; Kodera, T.; Nio, N.; Smirnov, S. V.; Samsonova, N. N.; Kozlov, Y. I.; Shimizu, S. Synthesis of 4-Hydroxyisoleucine by the Aldolase-Transaminase Coupling Reaction and Basic Characterization of the Aldolase from Arthrobacter Simplex AKU 626. Biosci. Biotechnol. Biochem. Jpn. 2007, 71, 1607-1615.

(26) Park, E. S.; Dong, J. Y.; Shin, J. S. Biocatalytic Asymmetric Synthesis of Unnatural Amino Acids through the Cascade Transfer of Amino Groups from Primary Amines onto Keto Acids. ChemCatChem 2013, 5, 3538-3542.

(27) Lo, H.-H.; Hsu, S.-K.; Lin, W.-D.; Chan, N.-L.; Hsu, W.H. Asymmetrical Synthesis of L-Homophenylalanine Using Engineered Escherichia Coli Aspartate Aminotransferase. Biotechnol. Prog. 2005, 21, 411-415.

(28) Li, T.; Kootstra, A. B.; Fotheringham, I. G. Nonproteinogenic $\alpha$-Amino Acid Preparation Using Equilibrium Shifted Transamination. Org. Process Res. Dev. 2002, 6, 533-538.

(29) Green, A. P.; Turner, N. J.; O’Reilly, E. Chiral Amine Synthesis Using $\omega$-Transaminases: An Amine Donor That Displaces Equilibria and Enables High-Throughput Screening. Angew. Chem. Int. Ed Engl. 2014, 53, 10714-10717.

(30) Zhao, G.; Winkler, M. E. A Novel Alpha-Ketoglutarate Reductase Activity of the SerA-Encoded 3-Phosphoglycerate Dehydrogenase of Escherichia Coli K-12 and Its Possible Implications for Human 2-Hydroxyglutaric Aciduria. J. Bacteriol. 1996, 178, 232-239.

(31) Heuson, E.; Charmantray, F.; Petit, J.-L.; de Berardinis, V.; Gefflaut, T. Enantioselective Synthesis of D- and 1- $\alpha$-Amino Acids by Enzymatic Transamination Using Glutamine as Smart Amine Donor. Adv. Synth. Catal. 2019, 361, 778-785.

(32) Guérard, C.; Alphand, V.; Archelas, A.; Demuynck, C.; Hecquet, L.; Furstoss, R.; Bolte, J. Transketolase-Mediated Synthesis of 4-Deoxy-D-Fructose 6-Phosphate by Epoxide HydrolaseCatalysed Resolution of 1,1-Diethoxy-3,4-Epoxybutane. Eur. J. Org. Chem. 1999, 1999, 3399-3402. 


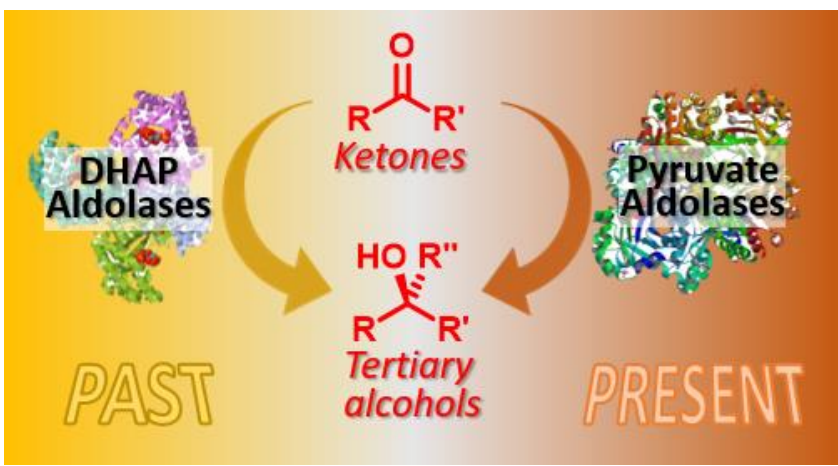

